\title{
The impact of underpricing of the default risk on investment: Evidence from Real Estate Investment Trusts (REITs)
}

\author{
Linh D. Nguyen and Bertram Steininger
}

Working Paper 2019:05

Division of Building and Real Estate Economics

Division of Banking and Finance

Department of Real Estate and Construction Management

School of Architecture and the Built Environment

KTH Royal Institute of Technology 


\title{
The impact of underpricing of the default risk on investment: Evidence from Real Estate Investment Trusts (REITs)
}

\author{
Linh D. Nguyen \\ RWTH Aachen University \\ Banking University of Ho \\ Department of Finance \\ Templergraben 64 \\ Chi Minh City \\ 52056 Aachen, Germany \\ wolfgang.breuer@ \\ rwth-aachen.de \\ Department of Finance \\ 36 Tôn Thất Đạm District 1, \\ Ho Chi Minh City, Vietnam \\ linh.nguyen@ \\ bfw.rwth-aachen.de

\section{Bertram Steininger} \\ KTH Royal Institute of Technology \\ Banking and Finance \\ Teknikringen $10 \mathrm{~B}$ \\ 10044 Stockholm, Sweden \\ bertram.steininger@abe.kth.se
}

\begin{abstract}
This study examines the impact of underpriced default risk on investment in the real estate investment trust (REIT) sector, where firms' investment is highly sensitive to changes in credit market conditions. The findings reveal that REITs exploiting underpriced default risk have a higher level of investment than their peers because the former can access low-cost capital. Moreover, exploiting the underpriced default risk is specific to not only REITs but also to the whole real estate investment sector. In contrast, underpriced default risk has an insignificant impact on investment of non-real estate firms because nonrecourse loans are unpopular in these firms.
\end{abstract}

Keywords: default risk, investment, real estate investment trust (REIT), underpricing of the default risk

JEL Classification: G21, G32 


\section{Introduction}

A put option on underlying assets is provided to borrowers when banks offer a non-recourse asset-backed mortgage loan (Pavlov \& Wachter, 2004). This put option gives the borrower the right to default. In particular, when the value of the underlying asset decreases below the outstanding loan balance, the borrower has the right to "put" the collateral back into the bank and walks away from any future obligations of the loan. The lender would not obtain any more compensation, even if the value of the collateral was less than the value of the defaulted amount.

Pavlov \& Wachter (2004) theoretically demonstrate that, if lenders underprice the put option embedded in non-recourse loans because they underprice the default risk of borrowers (hereafter underpricing of the default risk), the lenders charge an interest rate that is too low relative to the deposit interest rate (hereafter underpriced financing). Pavlov et al. (2015) find the significantly negative relationship between the lagged underpricing of the default risk and international real estate securities returns. The authors explain that companies are likely to perform inefficient financing activities, such as purchasing assets at inflated values, overinvesting and/or building corporate empires, which are enabled by underpriced financing. These activities would detract from firm value as underpriced financing disappears; hence, the firms exploiting the advantage of underpriced default risk seem to underperform.

This explanation implies that underpricing of the default risk is positively related to a firm's investment. However, the empirical evidence for this relationship has not been provided by either Pavlov et al. (2015) or previous studies, to the best of our knowledge. Therefore, the main aim of this study is to empirically investigate the relationship between underpriced 
default risk and investment, thereby contributing to the literature on drivers of a firm's investment.

This paper mainly focuses on the REIT sector because firms in this sector exhibit characteristics amplifying the effects of underpriced default risk on the rate of investment compared to other industries. Firstly, non-recourse loans are more popular in the real estate sector than in other industries because commercial mortgage loans are typically non-recourse (Hulse et al., 2016). Secondly, compared to non-real estate firms (non-REs), REITs have higher leverage (Breuer et al., 2019) and use bank loans more intensively (Hardin \& Wu, 2010). Hence, changes in lending interest rates could have a greater impact on their activities in general and investment in particular.

Furthermore, REITs' investment is also an interesting subject to investigate further. REITs are exogenously financially constrained firms due to their high mandatory dividend payout ratios; hence, only 7\% of REITs' investment is funded by retained earnings (Ott et al., 2005). Using external funds to finance investment due to a constraint on cash flow retention is likely to impede and distort efficient investment because external funds are more costly than internal funds (Myers \& Majluf, 1984). Hence, Riddiough \& Wu (2009) expect that REITs have invested at rates that are lower than the rates of investment of less financially unconstrained firms. However, the authors find that the rate of investment is generally equal or higher for REITs than for non-REs. Therefore, the second objective of this research is to explore how firm-level investment is affected in the sector in which firms are financially constrained.

Using a sample consisting of 1,685 firm-year observations for 201 equity REITs over a period from 1998 to 2015, the findings from this study provide empirical evidence supporting the positive relationship between underpriced default risk and investment. 
Specifically, REITs exploiting the underpricing of the default risk could obtain access to loans with a low rate of interest, thereby increasing their investment. A one standard deviation shock to underpricing of the default risk moves the rate of investment by about 2 percentage points, holding all other variables in the model constant and a mean value of $16 \%$ for the rate of investment. This finding is robust after controlling for crisis periods and a potential endogeneity bias or using alternative measures of investment and underpriced default risk. While not the main focus of this research, we find a significantly positive effect of the risk-reward trade-off or the default risk premium on investment, which has not been reported by previous studies. This finding suggests that firms that are forced to provide a higher return to investors due to a higher default risk are more likely to increase their investment because stock prices increase with investment (Lamont, 2000).

To provide a broader perspective on the impact of underpriced default risk on the rate of investment, this paper further investigates its impact on the sample of real estate operating companies (REOCs) and non-REs. The results show that underpricing of the default risk also has a significant effect on the investment of REOCs but insignificant for non-REs. Accordingly, underpricing of the default risk could be a prevalent symptom in the sector of real estate investment, but not in non-real estate firms. At first glance, this finding is attributable to the ratio of tangible assets to total assets (tangibility) that is lower for nonREs than for REITs. Hence, a further test is conducted on a matched sample, which is built based on the similarity of tangibility between REITs and non-REs. This investigation reveals that the insignificant relationship between investment and underpriced default risk in the non-RE sample is more likely due to non-recourse loans that are less popular in non-REs than in real estate investment firms (Hulse et al., 2016). Hence, non-REs are less likely to exploit the underpriced financing because the costs of default are higher for them than for "non-recourse" borrowers. 
In summary, the contribution of this research over the previous literature is to provide empirical evidence of a driver of the investment decision of real estate investment firms (REITs and REOCs), i.e. underpricing of the default risk. The rest of this paper is organised as follows. Section 2 gives a brief overview of the related literature. Section 3 outlines the method of measuring underpricing of the default risk, while Section 4 describes the data. Main results and robustness checks are discussed in Section 5 and Section 6, respectively. Section 7 provides further insights into the effects of the underpriced default risk in other industries before conclusions are drawn in Section 8 .

\section{The effects of underpricing of the default risk}

Pavlov \& Wachter (2006) and Pavlov et al. (2015) report that the presence of demand deposit insurance, limited liability, managers' myopia or a combination of these factors could induce banks to underprice the default risk of borrowers, thereby increasing lending volume and gaining short-term profits. Accordingly, underpricing behaviour is reported to have three effects on the economy and firms, i.e. inflated asset prices, stronger market crashes and lower stock returns.

Firstly, regarding inflated asset prices, Pavlov \& Wachter (2004) theoretically demonstrate that underpricing of the default risk reduces the lending rate and that it results in the market price of assets in fixed supply exceeding their fundamental price because the amount of underpricing is a component in the denominator of the function of the market price (see Pavlov \& Wachter (2004), pp. 149-150, for models that show how underpricing leads to inflated asset prices). Extending the theoretical model of Pavlov \& Wachter (2004), Pavlov \& Wachter (2006) analyse two competitive equilibria - good and underpricing, and account for the presence of many lenders. The authors demonstrate that underpriced default risk can trigger a race to the bottom for the lending rate. When the number of underpricing banks 
reaches a critical level, correctly pricing lenders would switch to the underpricing equilibrium and underpricing behaviour becomes inevitable.

Secondly, in terms of market crashes, Pavlov \& Wachter (2009) use a sample of REITs from 19 countries to examine the relationship between underpriced default risk and market crashes. Their analysis reveals that when a negative demand shock occurs, the countries exhibiting underpricing behaviour experience far deeper asset market crashes than correctly pricing economies do. The presence of underpriced default risk inflates asset prices. Hence, when there is a negative demand shock, the asset prices have to drop low enough to not only take away the prior price increases because of underpricing but also to capture the new supply and demand conditions. Similarly, Koh et al. (2005) document that underpricing of the default risk is one of the causes of the Asian real estate collapse in the 1990s.

Finally, underpricing of the default risk also has a significant impact on stock returns of borrowers. Specifically, Pavlov et al. (2015) find a significantly negative relationship between underpriced default risk and international real estate securities returns when they examine 585 REITs from 20 countries. The authors attribute this finding to REIT managers, who could gain a short-term benefit by taking advantage of underpriced financing but who expose themselves to potential long-term difficulties for two reasons. In particular, a rise in loan expenses is always potential because the underpriced financing could eventually vanish and operating risk is high because the market where underpricing is predominant is likely to encounter greater price decreases in an economic downturn. It is important to distinguish between the effect of underpriced financing on current asset prices and its effect on future returns. If current prices increase, future returns are going to be lower. In addition, managers who employ underpricing of the default risk are likely to focus on building their corporate empires. They grow the company beyond its optimum size or conduct investment decisions 
that reduce the firm value as underpriced financing disappears. Hence, REITs exploiting underpriced default risk seem to underperform.

The explanations for the three impacts of underpriced default risk imply that there is a potentially positive relationship between underpriced default risk and the rate of investment. However, no previous study has investigated this relationship. Thus, this research aims to analyse the impact of underpriced default risk on investment, thereby contributing to the literature on drivers of a firm's investment.

\section{Measuring underpriced default risk}

Pavlov \& Wachter (2009) develop a specific observable symptom of underpriced default risk in the economy. Specifically, underpricing of the default risk generates a negative correlation between asset returns and changes in the default spread, whereas correctly pricing results in no relationship between asset returns and changes in the default spread. Based on this finding, Pavlov et al. (2015) measure underpricing of the default risk as follows:

$$
\operatorname{CORR}_{i, t}=\rho\left(r_{i}, \Delta\right)
$$

where CORR is the value of the correlation between $r_{i}$ and $\Delta, \rho$ is the correlation function, $r_{i}$ is the monthly equity returns on firm $i$ and $\Delta$ is the monthly changes in the default spread. The lending spread consists of the default spread and remaining components, such as operating costs. Pavlov \& Wachter (2009) and Pavlov et al. (2015) document that these remaining components are relatively small and remain unchanged throughout the business cycle. Hence, they use the lending spread as a proxy for the default spread.

$$
<<\text { Insert Figure } 1 \text { here. }>>
$$

Figure 1 shows the correlation between the means of monthly equity returns, which are estimated as the average of monthly equity returns of all firms in the given month, and 
monthly changes in the default spread, which are estimated as monthly changes in the lending spread. The quadratic prediction line (the dashed line) appears to be as straight as the linear prediction line (the short-dash-dotted line). Therefore, the non-linear relationship between monthly equity returns and monthly changes in the default spread could be eliminated. The Pearson's correlation coefficient $(0.127, p$-value $=0.04)$ suggests that this correlation is different from 0 at the significance level of $5 \%$.

While only the negative values of correlation capture the symptom of underpriced default risk (Pavlov \& Wachter, 2009), the positive values could reflect the risk-reward trade-off or the default risk premium (Aretz et al., 2018). Thus, we divide CORR into two groups: the group of negative values (COR_NEG) and the group of positive ones (COR_POS). COR_NEG is equal to CORR for values of CORR less than zero and zero otherwise, thereby identifying underpricing of the default risk. COR_POS equals CORR for values of CORR greater than zero and zero otherwise, thereby capturing the risk-reward trade-off. This division allows the relationship between underpriced default risk and investment and the relationship between the risk-reward trade-off and investment to be asymmetric (Richardson, 2006). The effect of underpriced default risk on investment is the main focus of this research.

The width of the time window for calculating this correlation is an issue that deserves discussion. Changes in borrowing costs result in changes in real investment decisions, and changes in the investment need time to be manifested in equity returns. Accordingly, the width of the time window should be substantial enough to detect the symptom of underpriced default risk. However, if the time window is too long, the impact of changes in the default spread on stock prices can be diluted by other factors that also affect stock prices (Pavlov et al., 2015). Accordingly, the negative correlation between equity returns and changes in the default spread might no longer appropriately reflect the effect of underpriced default risk. 
Hence, the window should also be short enough to mitigate the smoothing effect. To ensure that underpricing of the default risk is adequately captured, time windows of 12,24 and 36 months are used simultaneously to calculate the correlation. Specifically, CORR12, CORR24 and CORR36 are the correlation between monthly equity returns and monthly changes in the default spread from time $t-12, t-24$ and $t-36$ to $t-1$, respectively.

\section{Data}

The sample comprises all constituent equity REITs of the FTSE NAREIT All REITs Index between 1998 and 2015 that are obtained from the website https://www.reit.com. To mitigate potential problems with survivorship bias, all historical constituent equity REITs are included in the sample. All data on the firm-level are obtained from Thomson Reuters Datastream/Eikon. Data on the difference between yields of a 10-year Treasury note and a 3-month Treasury bill are collected from the Federal Reserve Bank of St Louis's Economic Database. Since this study includes lagged variables, the first-year observations for each firm are lost. In addition, firm-year observations for which not all considered explanatory variables are available are excluded. Thus, the final REIT sample consists of 1,685 firm-year observations for 201 equity REITs over the period from 1999 to 2015. To ease the influence of extreme outliers, the sample is winsorised at the $1 \%$ and $99 \%$ levels for all continuous firm-specific variables.

$<<$ Insert Table 1 here. $>>$

The main dependent variable is the rate of investment (INVEST) while independent variables include underpriced default risk $\left(C O R_{-} N E G\right)$, the risk-reward trade-off (COR_POS), leverage ( $L E V)$, cash flow (CASHFLOW), tangibility $(T A N)$ and firm size (SIZE). To control for the effects of cash flow deriving from equity and debt issues, as well as the impact of growth or investment opportunities on the rate of investment, EQUITY_ISSUE, 
DEBT_ISSUE and GROWTH are included into the model. Also, term structure (T10Y3M) and lending rate ( $\left.L E N D I N G_{-} R A T E\right)$ are added to control for the influence of changes in costs of debt on a firm's investment. The definition of these variables is shown in Table 1.

Tables 2 and 3 present summary statistics and pairwise correlation coefficients, respectively. According to Table 2, the rate of investment is on average $16 \%$ of total assets that is in accordance with other studies (see, e.g., Alcock \& Steiner, 2017; Ott et al., 2005). Regarding the variables of underpriced default risk (COR_NEG12,COR_NEG24 and COR_NEG36), their means (absolute value) and standard deviations decrease with the increase of the time window width for calculating the correlation. This result is consistent with the above discussion that the symptom of underpriced default risk could be smoothed by other factors if the time window is longer. Table 3 shows the pairwise correlation coefficients between the independent variables. Generally, the predictors show low levels of correlation, except the correlations between COR_NEG24 and COR_NEG36 and between COR_POS24 and COR_POS36. However, this is not a concern since they are regressed in separate models.

$$
\begin{aligned}
& <<\text { Insert Table } 2 \text { here. }>> \\
& <<\text { Insert Table } 3 \text { here. }>>
\end{aligned}
$$

\section{Underpricing of the default risk and investment}

Underpricers could decrease lending rates to increase their lending volume, thereby gaining more short-term benefits based on firm performance. If borrowers exploit the underpricing of the default risk, they could access low-cost capital and generate excess free cash flow that could be used to pursue new investment projects, among others. Hence, underpriced default risk is expected to have a positive impact on REITs' investment. The following panel data regression model is conducted to test this expectation: 
$\operatorname{INVEST}_{i, t}=\alpha+\beta_{1}$ COR_NEG $_{i, t-1}+\beta_{2}$ COR_POS $_{i, t-1}+\beta_{3}$ FIRM $_{i, t-1}+\beta_{4}$ MARKET $_{i, t}+\varepsilon_{i, t},(2)$

where $F I R M$ is a vector comprising firm-specific characteristic variables, specifically $L E V$, CASHFLOW, GROWTH, TAN, SIZE, EQUITY_ISSUE and DEBT_ISSUE. The vector MARKET includes T1OY3M and LENDING_RATE. The parameters $\beta_{i}$ comprise the estimated coefficients, while $\varepsilon_{i, t}$ consists of the error terms of the model. All explanatory variables, except $T 10 Y 3 M$ and $L E N D I N G \_R A T E$, are lagged by one year to mitigate concerns regarding reverse causality problems.

Table 4 presents the results of this analysis. Underpricing of defaulted risk using the time window of 12 months (COR_NEG12) is presented in Model 1, while COR_NEG24 in Model 2 and COR_NEG36 in Model 3. Hausman's specification test indicates that the fixed effects model is the most appropriate specification for the data (see Panel A of Table A.1 in the Appendix). Standard errors are clustered by the firm level to be robust to autocorrelation and heteroscedasticity. The main variables of interest are COR_NEG12,COR_NEG24 and COR_NEG36 that capture the effects of underpriced default risk.

$<<$ Insert Table 4 here. $>>$

This analysis shows that the estimated coefficient of COR_NEG12 is significantly negative. The equity returns on REITs exploiting underpriced financing have a negative relationship with changes in the lending spread. The investment of these companies is likely to be higher than that of their peers (note that the sign of $C O R \_N E G$ is negative), as is the expectation. When the exploitation of underpriced debt becomes more explicit, which makes the negative correlation between equity returns on "exploiters" and changes in the lending spread becomes stronger, the positive impact of underpriced default risk on the rate of investment is larger. For example, the coefficient of -0.125 implies an increase of investment by 2 
percentage points if this correlation moves by one standard deviation shock (0.174) holding all other variables in the model constant and a mean value of $16 \%$ for the rate of investment. Since changes in term structure and lending interest rates are controlled by adding T10T3M and LENDING_RATE, this finding is robust to controlling for changes in the cost of debt financing.

When the longer time windows are used, the effects of changes in the lending spread, which result from the decision of short-term bank managers who intentionally underprice their borrowers' default risk to increase the lending volume or capture a larger market share, on stock prices could be diluted by other factors that also affect the movement of stock prices. Hence, the negative correlation between equity returns and changes in the default spread might not adequately capture the impact of underpriced default risk and thus has an insignificant impact on a firm's investment. This reasoning is supported by the insignificant coefficients of COR_NEG24 and COR_NEG36.

While not the focus of this research, the regression findings in Table 4 also show the effect of the risk-reward trade-off or the default risk premium $\left(C O R_{-} P O S\right)$ on investment, which has not been reported by previous studies. Similarly to the underpricing of the default risk, the risk-reward trade-off is only significantly positively related to investment when the time window of 12 months is used. The positive relationship between COR_POS12 and the rate of investment suggests that firms which are forced to provide a higher return to investors due to a higher default risk are more likely to increase their investment because stock prices increase with investment (Lamont, 2000). However, further investigations are needed to examine the robustness of this finding and future studies on the current topic are thus recommended. 
Regarding firm-specific variables, the analysis shows that the sensitivity of cash flow to investment is significantly positive, which is in line with previous results (see, e.g., Aivazian et al., 2005; Carpenter \& Guariglia, 2008). For example, the coefficient (0.932) of CASHFLOW in Model 1 indicates that the elasticity of investment with respect to cash flow, evaluated at sample means, is $0.297(0.932 \times 0.051 / 0.160$, where 0.051 is the mean of CASHFLOW and 0.160 is the mean of INVEST). Hence, a $10 \%$ increase in the cash flow-toasset ratio leads to an increase in investment of 2.97 percentage points, all else equal. The regression findings also show that REITs with higher investment opportunities (GROWTH) have a higher rate of investment relative to their peers.

The impacts of equity issue and debt issue on investment are also significantly positive. For instance, all else equal in Model 1, the rate of investment is, on average, 6.3 and 5.0 percentage points higher for REITs conducting equity issues and debt issues than for REITs that do not issue equity and debt, respectively. This finding comes as no surprise since REITs rely on external funds to finance their investment due to their high mandatory dividend payout ratios.

In contrast, a negative correlation is found between the rate of investment and leverage. The estimated coefficient in Model $1,-0.272$, suggests that the investment to total assets ratio decreases by about 2.72 percentage points when the leverage level increases by 0.1 . This magnitude of this effect is similar to the effect of leverage on industrial firms' investment, 2.26 percentage points, that is reported in Aivazian et al. (2005). This finding supports agency theories of corporate leverage. In addition, the rate of investment is significantly negatively related to firm size, suggesting that smaller-sized REITs display higher investment rates than larger-sized REITs. 
Regarding market variables, this investigation reveals that both term structure and lending interest rate have a significantly negative impact on REITs' investment. These findings suggest that an increase in lending interest rate decreases REITs' investment since REITs depend on liquidity provided by banks as they develop or acquire new properties (Hardin \& Wu, 2010). Furthermore, REITs use more long-term debt than short-term debt (Alcock et al., 2014; Breuer et al., 2019), the increase in the interest rate of long-term capital relative to short-term, therefore, would decrease REITs' investment.

\section{Robustness checks}

\subsection{Controlling for effects of the crisis period}

Following the Senior Loan Officer Opinion Survey on Bank Lending Practices conducted quarterly by the Board of Governors of the Federal Reserve System (https://www.federalreserve.gov/data/sloos.htm.), both supply and demand for bank loans highly fluctuate in financial crises. Hence, we investigate to what extent the results are stable during financial crises. To control for the effects of the crises, a dummy variable (D_CRISIS) is included in Eq. (2). Its interaction term with underpriced default risk $\left(C O R_{-} N E G \times D_{-} C R I S I S\right)$ is also considered to compare the influence of underpriced default risk between normal times and crisis times. From 1998 to 2015, the Business Cycle Dating Committee of the National Bureau of Economic Research (NBER) states that 2001, 2007, 2008 and 2009 are years of recession (https://www.nber.org/cycles.html). Hence, D_CRISIS is defined to be equal to 1 for the years 2001, 2007, 2008 or 2009 and 0 otherwise.

Table 5 presents the results of this investigation. The analysis supports the previous finding that COR_NEG12 is significantly positively related to investment and the effects for COR_NEG24 and COR_NEG36 are insignificant. The coefficients of D_CRISIS are negative in all models. For example, the rate of investment in crises is, on average, 3.0 percentage points lower than it is in normal times in Model 1 (COR_NEG12). However, all 
interaction terms are insignificant in all models, suggesting there is no statistical difference in the effect of underpriced default risk on investment between normal times and crisis times. This finding implies that REITs in the sample always exploit underpriced default risk to finance their investment regardless of the features of periods (normal or recession) since they are exogenously financially constrained firms.

$<<$ Insert Table 5 here. $>>$

\subsection{Controlling for endogeneity}

It is possible that the measure of underpriced default risk is endogenously determined. The characteristics of a firm which cause it to exploit underpriced default risk could also cause a change in the rate of investment. In other words, there might be some omitted variables affecting both underpriced default risk and investment, thereby leading to a correlation between the proxies for underpriced default risk and the error term, $\varepsilon_{i, t}$. In particular, a firm having many potential investment projects might be more likely to increase the exploitation of underpriced default risk. Hence, an instrumental variable approach should be used to alleviate this endogeneity bias.

Since the existing literature does not provide suitable instruments for underpriced default risk, this research develops new instruments and evaluates their reliability. We use the annual growth of bonuses $\left(B O N U S_{-} G R\right)$ and that of wages $\left(W A G E \_G R\right)$ of employees in the industry of "Federal Reserve banks, credit intermediation and related activities" (data are obtained from the Economic Time Series Page - http://www.economagic.com/nipa.htm) as instruments. BONUS_GR is defined as the natural logarithm of the ratio of bonuses of employees at year $t$ to bonuses of employees at year $t-1$. WAGE_GR is calculated as the natural logarithm of the ratio of wages at year $t$ to wages at year $t-1$. The rationale for choosing these instruments is that the increase in annual bonuses or wages in the previous 
year $(t-1)$ could induce short-term bank managers to increase the lending volume in the present year $(t)$, so that they could receive more bonuses payments. One way to increase lending volume is to intentionally underprice the default risk of borrowers and reduce the lending interest rate. Therefore, these two instruments could have a direct impact on underpriced default risk, but they do not have a direct influence on REITs' investment.

After determining BONUS_GR and WAGE_GR, a two-stage least squares approach (2SLS) is used to estimate the effects of underpriced default risk on investment. In the first stage, underpriced default risk is regressed on all independent variables in Eq. (2) and the two instruments. In the second stage, COR_NEG is replaced with its predicted values from the first stage and the Eq. (2) is re-run. The results of these 2SLS are reported in Table 6. Models 1, 3 and 5 present the results of the first stage while Models 2, 4 and 6 present those of the second stage.

$$
<<\text { Insert Table } 6 \text { here. }>>
$$

In the first stage, both BONUS_GR and WAGE_GR have significant effects on underpriced default risk. Annual bonuses appear to increase the symptom of underpriced default risk, whereas wages have a negative impact on underpriced default risk. The findings suggest that a higher bonus could induce lenders to underprice their borrowers' default risk. In contrast, a higher level of wages, which are fixed incomes and are not influenced by the firm performance, could prevent underpricing behaviour.

The validity of these two instruments is confirmed by the Sanderson-Windmeijer (SW) multivariate $F$ test of excluded instruments (Sanderson \& Windmeijer, 2016) and the Hansen $J$ statistic (Baum et al., 2007), which are reported at the bottom of Table 6. The SW multivariate $F$ test confirms that the null hypothesis $\left(\mathrm{H}_{0}\right.$ : instruments can be excluded from the first-stage regressions) is rejected, which suggests that the instruments are not weak. 
Similarly, the Hansen $J$ statistic is far from the rejection of its null hypothesis $\left(\mathrm{H}_{0}\right.$ : the instruments are valid instruments). Therefore, these two instruments are appropriate for our analysis.

In the second stage, the findings reveal that the estimated coefficients of COR_NEG12 and COR_NEG24 are significantly negative, while COR_NEG36 keeps the insignificant impact on the rate of investment. In addition, the economic significance of COR_NEG12's influence also significantly increases after controlling for the endogeneity bias. Specifically, the estimated coefficient, -0.342 , suggests that, ceteris paribus, a one standard deviation shock to underpricing of the default risk moves the rate of investment by about 6 percentage points $(0.342 \times 0.174)$. Therefore, the outcomes of this investigation confirm that the impact of underpriced default risk on the rate of investment is robust and is not due to omitted variables or a reverse causality problem.

\subsection{Alternative measures of investment}

The literature provides two types of definition of investment - inflow or outflow: inflow is based on sources of financing that fund investment activities (see, e.g., Alcock \& Steiner, 2017; Ott et al., 2005) and outflow is based on total investment expenditure (see, e.g., Lang et al., 1996; Richardson, 2006). In all models used so far, the rate of investment is measured with the first type. To test whether the results are unaffected by using alternative measures of investment, the rate of investment could be calculated as the second type. The finance literature provides two definitions of investment regarding the second type. The first definition calculates the rate investment as the sum of capital expenditures, acquisitions and research and development less cash receipts from the sale of property, plant and equipment, then divided by total assets (INVEST-CASH) (Richardson, 2006). The second one estimates the rate of investment as capital expenditures minus depreciation, then scaled by total assets 
(INVEST-DEPR) (Lang et al., 1996). Since there is no evidence supporting which measure is better, both measures are used. Hence, the analyses in Section 5 are re-conducted by replacing INVEST with INVEST-CASH and INVEST-DEPR as dependent variables.

The results are presented in Table 7. Once again, the investigation shows that only COR_NEG12 has significantly negative coefficients in both models of INVEST-CASH and INVEST-DEPR. This outcome assures that the main findings are robust even when controlling for funding and expenditure of investments. In summary, the outcomes of these robustness checks confirm that underpricing of the default risk has a significantly positive impact on the rate of investment in the REIT sector.

$$
<<\text { Insert Table } 7 \text { here. }>>
$$

\subsection{An alternative measure of underpriced default risk}

Certainly, the measure of underpriced default risk has some limitations. Firstly, underpriced default risk cannot be directly measured. Instead, the correlation between equity returns and changes in the default spread is used as an observable symptom of underpriced default risk. Second, the default spread, which is only one component of the lending spread, is assumed to equal the lending spread. Hence, this section uses a model to estimate default risk for individual firms, thereby calculating underpriced default risk.

Vassalou \& Xing (2004) use the option pricing model of Merton (1974) to estimate the default risk for individual firms (henceforth Merton model). Empirical studies show that this model could create a good default measure for individual firms (see, e.g., Gropp et al., 2006; Mitra \& Duggar, 2009). Hence, this research uses the Merton model to calculate an alternative measure of underpriced default risk.

Following Vassalou \& Xing (2004), the default likelihood indicator (DLI) for individual firms is estimated as follows: 


$$
D L I=N\left(-\frac{\ln \left(V_{A, t} / X_{t}+\left(\mu-\frac{1}{2} \sigma_{A}^{2}\right) T\right.}{\sigma_{A} \sqrt{T}}\right)
$$

where $N$ is the cumulative density function of the standard normal distribution, $V_{A}$ is the firm's assets value, $X$ is the book value of debt, $\mu$ is an instantaneous drift, $\sigma_{A}$ is an instantaneous volatility of assets value, $T$ is the maturity of debt (for the detailed calculation procedure, see Vassalou \& Xing (2004), pp. 835-837).

The default likelihood indicator reflects the default probability of a firm and ranges from 0 to 1. Figure 2 depicts the aggregate default likelihood indicator for all REITs in the sample. The aggregate $D L I$ is calculated as the mean of the $D L I$ of all REITs. The shaded areas represent recession periods as defined by NBER. The graph indicates that the probability of default highly fluctuates before and in crises and reaches a peak in the 2008 financial crisis with $14 \%$.

$$
<<\text { Insert Figure } 2 \text { here. }>>
$$

To capture the underpriced default risk, three assumptions are made. Firstly, banks use the Merton model to assess borrowers' default risk. Secondly, lines of credit are negatively related to borrowers' default risk, i.e. borrowers would access a higher line of credit if their default risk decreased and vice versa. Thirdly, the default risk premium is constant, or lending interest rates are not influenced by borrowers' default risk. Accordingly, if total lines of credit available to the borrowers increase with the increase of their probability of default, this situation should be explained as a consequence of the underpricing of the default risk of borrowers by lenders.

Based on this reasoning, the new measure of underpriced default risk $\left(N E W_{-} C O R \_N E G\right)$ is generated as an indicator variable that takes the value of 1 if a firm-year observation has 
simultaneously a positive change in $D L I$ and a positive change in the ratio of total lines of credit available to total assets and zero otherwise. The change in $D L I$ is calculated as the difference in $D L I$ between year $t$ and year $t-1$, while the change in the ratio of total lines of credit available to total assets is defined as the difference in this ratio between year $t$ and year $t-1$. Next, Eq. (2) is re-run, but COR_NEG and COR_POS are replaced by $N E W \_C O R \_N E G$ or $D L I$.

Table 8 reports the results of this analysis. INVEST, INVEST-CASH and INVEST-DEPR are the dependent variables of models in Panels A, B and C, respectively. Models 1, 3 and 5 show the results of the model using $N E W \_C O R \_N E G$ while Models 2, 4 and 6 examine the impact of $D L I$ on investment. All estimated coefficients of $N E W_{-} C O R_{-} N E G$ are significantly positive which suggests that underpricing of the default risk has a significant influence on the rate of investment in the REIT sector. For example, in Model 1, the rate of investment is, on average, 12.4 percentage points higher for those years exhibiting the symptom of underpriced default risk than it is for years without underpriced default risk, all else equal.

Furthermore, the analysis also provides evidence that REITs with a higher default probability have a lower rate of investment than their peers. A one standard deviation increase in $D L I$ is associated with a decrease of 1.2 percentage points in investment $(-0.152 \times 0.080$, where 0.152 is the coefficient of $D L I$ in Model 2 and 0.080 is the standard deviation of $D L I$ ). When the default risk increases, it is more difficult for firms to access sources of external funds. Hence, these firms are more likely to have a shortage of capital to finance their investment. Overall, these findings support the main finding in Section 5 that underpricing of the default risk increases the rate of investment in the REIT sector.

$<<$ Insert Table 8 here. $>>$ 


\section{The effect in other industries}

In principle, all debt has an embedded put option - default. However, costs of default for borrowers are different between recourse and non-recourse loans. If the loan is a nonrecourse loan, the default option is very valuable to the borrowers, because they just walk away from the failed project. In contrast, a default may be more costly for the borrowers if the loan is a recourse loan because the lender can lay claim to other assets owned by the borrowers to help them recover their original loan.

Sections 5 and 6 confirm that exploiting underpriced default risk could increase the rate of investment in the REIT sector, where non-recourse loans are popular. This section tests whether the impact of underpriced default risk on investment is REIT-specific or whether it also exists in the entire real estate investment sector and other industries. Accordingly, we could conclude whether the negative correlation between equity returns and changes in the default spread can be used as an observable symptom of underpricing in the industries, where non-recourse loans are less popular.

For this purpose, the non-RE sample and the REOC sample are used. The non-RE sample consists of non-real estate firms, while the REOC sample includes listed real estate operating companies, which operate in a similar line of business as REITs but are taxable firms. The two samples are built from the Datastream universe. Regarding the non-RE sample, a company must fulfil the following criteria to be included in this sample: 1) listed on AMEX, NASDAQ or NYSE; 2) currency is listed in USD; 3) categorised as equity and 4) it is not in the financial sectors, specifically bank, financial services, life insurance, nonlife insurance, real estate investment and services and real estate investment trust, following the Industry Classification Benchmark. For the REOC sample, the fourth criterion of the non-RE sample is replaced by the ICB sector "Real Estate Investment and Services". Similarly to the REIT sample, these two samples include both active and inactive companies to alleviate a 
survivorship bias. After lagging and excluding firm-year observations with missing values of any relevant variables, the non-RE sample covers 30.952 firm-year observations for 2,586 non-REs, while the REOC sample covers 561 firm-year observations for 59 REOCs. The summary statistics are presented in Table A.2 in the Appendix.

To examine the difference in the impact of COR_NEG on the rate of investment between REITs and REOCs as well as between REITs and non-REs, two joint samples (the REITREOC sample and the REIT-non-RE sample) and interaction terms between the indicator variable for REITs ( $\left.D \_R E I T\right)$ with underpriced default risk are analysed. The REIT-REOC sample consists of REITs and REOCS, and $D_{-} R E I T$ takes a value of 1 for REITs and 0 for REOCs. The REIT-non-RE sample includes REITs and non-REs and $D_{-} R E I T$ takes a value of 1 for REITs and 0 for non-REs. Since REOCs operate in the same industry as REITs, we expect that there is no difference in the effect of underpriced default risk on investment between REITs and REOCs. In contrast, this effect is expected to be distinct between REITs and non-REs because they have a different nature of assets and are exposed to different market conditions.

The results of the analyses are reported in Table 9. Panel A presents the results of the REITREOC sample, while Panel B shows the results of the REIT-non-RE sample. In Panel A, COR_NEG12 has a significant influence on investment, while the coefficient of the interaction term is insignificant. This finding suggests that underpriced default risk has a significant effect on investment in the general sector of real estate and its effects are not different between REITs and REOCs, as is our expectation. In contrast, Panel B shows that the coefficient of COR_NEG12 is insignificant, while the coefficient of the interaction term between $D \_R E I T$ and COR_NEG12 is significant at the level of $1 \%$. This result, combining with the main result reported in Section 5, implies that the effect of underpriced default risk 
on the rate of investment is significant for REITs but is insignificant for non-REs as expected.

$$
<<\text { Insert Table } 9 \text { here. }>>
$$

The insignificant result of underpriced default risk for non-REs might be driven by the fact that they have less tangibility than REITs ( 0.278 vs. 0.845$)$. In order to check this conjecture, a propensity score analysis is used to find for each REIT-year observation a corresponding non-RE-year observation based on the magnitude of tangibility (TAN). This procedure generates a matched sample that consists of 797 REIT-year observations and 1,530 non-REyear observations. In this matched sample, the mean of $T A N$ is 0.783 for REITs and 0.754 for non-REs. The analysis in Section 5 is repeated for COR_NEG12. The results once again document that COR_NEG12 has a significantly positive impact on REITs' investment but not on non-REs' investment. Besides, the difference in the effects of underpriced default risk on investment between REITs and non-REs is statistically significant. Details are available in Table A.3.

Taken together, these results reveal that underpriced default risk does not appear to affect the investment decisions of non-REs. At first glance, this is attributable to non-REs that do not have as many tangibility as REITs have. However, the results in the matched sample reveal that high-tangibility non-REs also exhibit an insignificant relationship between investment and underpriced default risk. There are two potential explanations for this finding. Firstly, real estate assets, which play the role of valuable collateral to apply for commercial mortgage loans, might not account for a significant percentage of total assets of non-REs, even high-tangibility non-REs. Secondly, non-recourse loans are less popular in non-REs; hence, non-REs are less likely to exploit the underpriced financing because costs of default are higher for them than for "non-recourse" borrowers. Accordingly, the negative 
correlation between equity returns and changes in the default spread can be used as an observable symptom of underpricing in the real estate investment sector (REITs and REOCs), but not in other industries.

\section{Conclusion}

REITs highly rely on liquidity provided by banks to finance their investment due to the mandatory requirement of dividend payment (Hardin \& Wu, 2010). Therefore, REITs' investment is more likely to be highly sensitive to changes in lending interest rates. Accordingly, underpriced default risk, which decreases the lending interest rate, could exaggerate REITs' investment. However, this impact has not been examined so far. Hence, this research contributes to the literature on drivers of a firm's investment by documenting the role of underpriced default risk on investment decisions of REITs.

The evidence from this study reveals that underpricing of the default risk has a significantly positive impact on the rate of investment in the REIT sector, as was expected. Specifically, a one standard deviation increase in exploiting underpriced default risk is associated with a 2 percentage-point increase in the rate of investment, which is on average $16 \%$ of total assets for all REITs. Furthermore, the analyses show that cash flow, equity issue and debt issue increase the rate of investment, whereas leverage, firm size and the market variables are negatively related to investment.

By verifying whether the effect of the underpricing of the default risk on investment is realestate-wide or regulation-specific, we find evidence that it occurs in general for firms with a focus on the asset class of real estate (REITs and REOCs), whereas it is insignificant for non-real estate firms (non-REs). This finding may be attributable to non-recourse loans that are unpopular in non-REs (Hulse et al., 2016). Hence, non-REs do not seem to exploit the 
underpriced financing because the costs of default are higher for them than for "nonrecourse" borrowers.

Taking a closer look at possible causes for the main finding, we expand the analysis by the effects of financial crises and endogeneity bias. In addition, we examine the robustness of this finding across the alternative measures of investment and underpriced default risk. Hence, four robustness checks are performed. The results confirm that the effects of underpriced default risk are unaffected by financial crises, the endogeneity bias, using alternative measures of investment, as well as using an alternative proxy for underpriced default risk.

After excluding these other explanations, we hope that our results will point towards new avenues of future research into the relationship between underpricing of the default risk on investment, taking further aspects into account for which we have no or only limited data. Firstly, characteristics of managers that could control the impact of underpriced default risk, such as long-term tenure vs. short-term tenure or internal manager vs. external manager, have not been considered due to the limitation of data. Secondly, the influence of underpriced default risk has not been directly measured. Instead, its impact is indirectly identified via the correlation between equity returns and the default spread or the positive relationship between changes in the default probability and changes in total debt. Therefore, further studies could be carried out to enhance the results of this research.

Last but not least, we provide evidence for the positive relationship between the risk-reward trade-off and a firm's rate of investment, which has not been documented by previous research. Since this finding is not the main focus of this paper, further investigations are needed to examine the robustness of this result and future studies on the current topic are thus recommended. 


\section{Reference}

Aivazian, V. A., Ge, Y., \& Qiu, J. The impact of leverage on firm investment: Canadian evidence. Journal of Corporate Finance, 2005, 11:1-2, 277-91.

Alcock, J., \& Steiner, E. The interrelationships between REIT capital structure and investment. Abacus, 2017, 53:3, 371-94.

Alcock, J., Steiner, E., \& Tan, K. J. K. Joint leverage and maturity choices in real estate firms: the role of the REIT status. Journal of Real Estate Finance and Economics, 2014, 48:1, 57-78.

Aretz, K., Florackis, C., \& Kostakis, A. Do stock returns really decrease with default risk? New international evidence. Management Science, 2018, 64:8, 3821-42.

Baum, C. F., Schaffe, M. E., \& Stillman, S. Enhanced routines for instrumental variables/generalized method of moments estimation and testing. Stata Journal, 2007, $7: 4,465-06$.

Breuer, W., Nguyen, L. D., \& Steininger, B. I. Decomposing industry leverage: the Real Estate Investment Trust (REIT) debt puzzle. Available at SSRN: https://ssrn.com/abstract=3259946, 2019.

Carpenter, R. E., \& Guariglia, A. Cash flow, investment, and investment opportunities: new tests using UK panel data. Journal of Banking and Finance, 2008, 32:9, 1894-906.

Chou, W. H., Hardin, W. G., Hill, M. D., \& Kelly, G. W. Dividends, values and agency costs in REITs. Journal of Real Estate Finance and Economics, 2013, 46:1, 91-114.

Frank, M. Z., \& Goyal, V. K. Capital structure decisions: which factors are reliably important? Financial Management, 2009, 38:1, 1-37.

Gropp, R., Vesala, J., \& Vulpes, G. Equity and bond market signals as leading indicators of bank fragility. Journal of Money, Credit and Banking, 2006, 38:2, 399-28.

Hardin, W. G., \& Hill, M. D. REIT dividend determinants: excess dividends and capital markets. Real Estate Economics, 2008, 36:2, 349-69.

Hardin, W. G., \& Wu, Z. Banking relationships and REIT capital structure. Real Estate Economics, 2010, 38:1, 257-84.

Hulse, B. D., Christophorou, P. L., \& Guida, P. A. Sample nonrecourse loan carveout and springing recourse provisions with borrow comments. Practical Lawyer, 2016, 62:1, 49-58.

Koh, W. T. H., Mariano, R. S., Pavlov, A., Phang, S. Y., Tan, A. H. H., \& Wachter, S. M. Bank lending and real estate in Asia: market optimism and asset bubbles. Journal of Asian Economics, 2005, 15:6, 1103-18.

Lamont, O. A. Investment plans and stock returns. Journal of Finance, 2000, 55:6, 271945.

Lang, L., Ofekb, E., \& Stulz, R. M. Leverage, investment and firm growth. Journal of Financial Economics, 1996, 40:1, 3-29.

Lundstrum, L. L. Corporate investment myopia: a horserace of the theories. Journal of Corporate Finance, 2002, 8:4, 353-71.

Merton, R. C. On the pricing of corporate debt: the risk structure of interest rates. Journal of 
Finance, 1974, 29:2, 449-70.

Mitra, S., \& Duggar, E. External linkages and contagion risk in Irish banks. IMF Staff Papers, 2009, 56:4, 758-86.

Morri, G., \& Beretta, C. The capital structure determinants of REITs. Is it a peculiar industry? Journal of European Real Estate Research, 2008, 1:1, 6-57.

Myers, S. C., \& Majluf, N. S. Corporate financing and investment decisions when firms have information that investors do not have. Journal of Financial Economics, 1984, 13:2, $187-21$.

Ooi, J. T. L., Ong, S. E., \& Li, L. An analysis of the financing decisions of REITs: the role of market timing and target leverage. Journal of Real Estate Finance and Economics, 2010, 40:2, 130-60.

Ott, S. H., Riddiough, T. J., \& Yi, H.-C. Finance, investment and investment performance: evidence from the REIT sector. Real Estate Economics, 2005, 33:1, 203-35.

Pavlov, A., Steiner, E., \& Wachter, S. Macroeconomic risk factors and the role of mispriced credit in the returns from international real estate securities. Real Estate Economics, 2015, 43:1, 241-70.

Pavlov, A., \& Wachter, S. Robbing the bank: non-recourse lending and asset prices. Journal of Real Estate Finance and Economics, 2004, 28:2-3, 147-60.

Pavlov, A., \& Wachter, S. The inevitability of marketwide underpricing of mortgage default risk. Real Estate Economics, 2006, 34:4, 479-96.

Pavlov, A., \& Wachter, S. Mortgage put options and real estate markets. Journal of Real Estate Finance and Economics, 2009, 38:1, 89-103.

Richardson, S. Over-investment of free cash flow. Review of Accounting Studies, 2006, $11: 2-3,159-89$.

Riddiough, T. J., \& Wu, Z. Financial constraints, liquidity management and investment. Real Estate Economics, 2009, 37:3, 447-81.

Sanderson, E., \& Windmeijer, F. A weak instrument F-test in linear IV models with multiple endogenous variables. Journal of Econometrics, 2016, 190:2, 212-21.

Sun, L., Titman, S. D., \& Twite, G. J. REIT and commercial real estate returns: a postmortem of the financial crisis. Real Estate Economics, 2015, 43:1, 8-36.

Vassalou, M., \& Xing, Y. Default risk in equity returns. Journal of Finance, 2004, 59:2, 831-68.

Acknowledgements: We would like to thank Eva Steiner for her valuable suggestions. We are also grateful for comments from Charles Ka Yui Leung and other participants of the European Real Estate Society Conference 2019 in Cergy, France. 


\section{Figure and Tables}

\section{Figure 1: Correlation between default spread and equity returns}

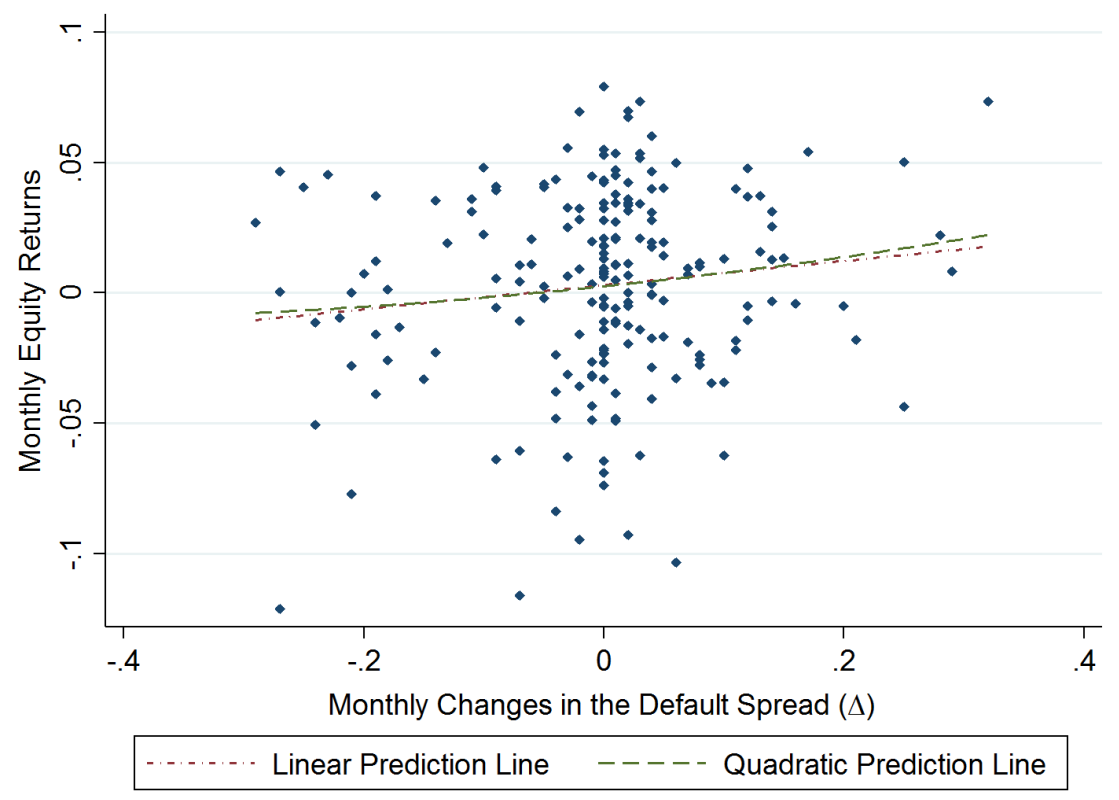

The figure shows monthly changes in the default spread $(\Delta)$ on the horizontal axis and the mean of monthly equity returns $(\bar{r})$ on the vertical axis. The mean of monthly equity returns is the average of monthly equity returns of all firms in the given month. Each diamond represents the mean values of monthly equity returns and monthly changes in default spread in the given month. The short-dash-dotted line is the resulting line of the prediction for $\bar{r}$ from an OLS regression of $\bar{r}$ on $\Delta$ while the dashed line is the resulting curve of the prediction for $\bar{r}$ from an OLS regression of $\bar{r}$ on $\Delta$ and $\Delta^{2}$. 
Figure 2: Aggregate default likelihood indicator

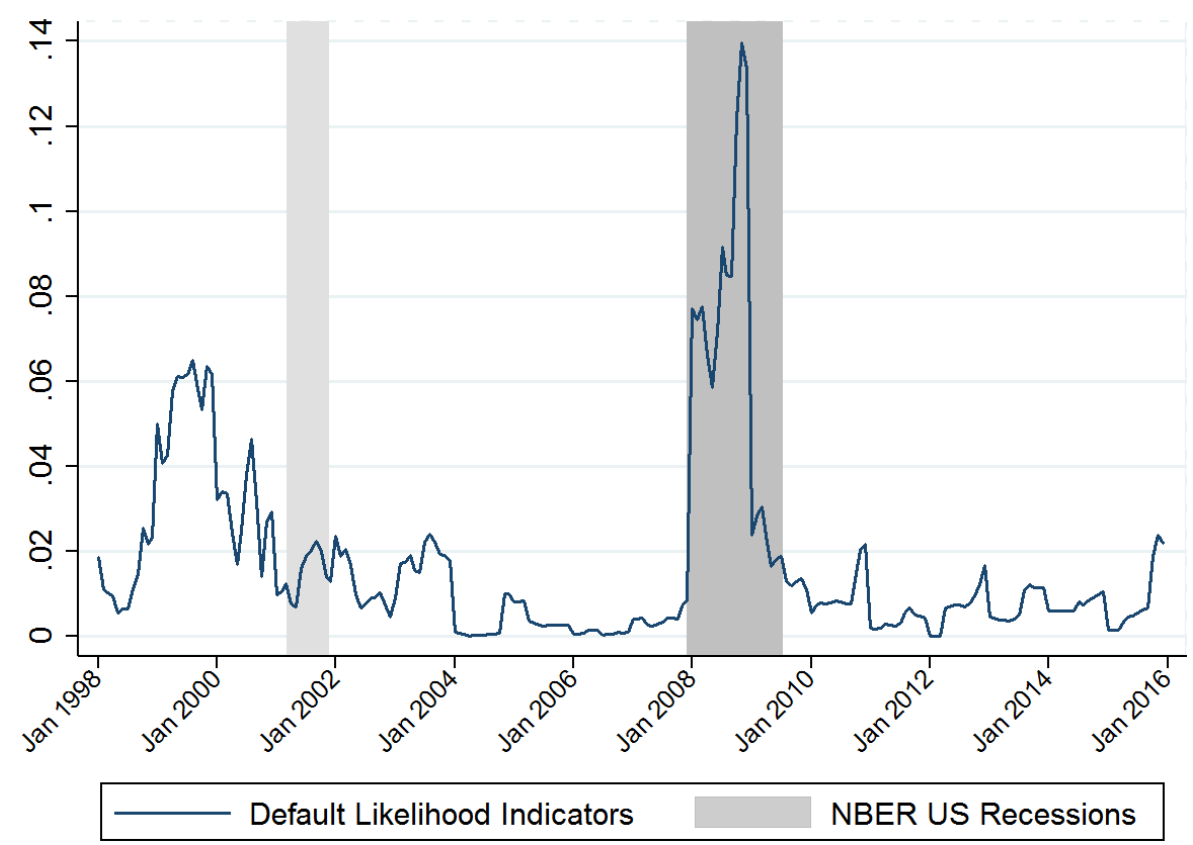

The figure shows the aggregate default likelihood indicator $(D L I)$ based on Vassalou \& Xing (2004) of firms in the sample from 1998 to 2015 . The aggregate $D L I$ is defined as the simple average of the $D L I$ of all firms. The shaded areas denote recession periods, as defined by the National Bureau of Economic Research (NBER). 
Table 1: Definition of variables

\begin{tabular}{|c|c|c|}
\hline Name & Measurement & Reference \\
\hline Rate of investment (INVEST) & $\begin{array}{l}\text { (Change in book capital + depreciation) / total assets, } \\
\text { where book capital is the book value of equity, book } \\
\text { value of short-term debt and book value of long-term } \\
\text { debt }\end{array}$ & $\begin{array}{l}\text { Alcock \& Steiner (2017); } \\
\text { Ott et al. (2005) }\end{array}$ \\
\hline Correlation $(C O R R n)$ & $\begin{array}{l}\text { Correlation between monthly equity returns and } \\
\text { monthly changes in the default spread in the time } \\
\text { windows of } n \text { months, where } n \text { is } 12,24 \text { and } 36 \\
\text { months }\end{array}$ & $\begin{array}{l}\text { Pavlov \& Wachter (2009); } \\
\text { Pavlov et al. (2015) }\end{array}$ \\
\hline $\begin{array}{l}\text { Underpricing of defaulted risk } \\
\left(C O R_{-} N E G n\right)\end{array}$ & $\begin{array}{l}\text { Equal CORRn for values of CORRn less than zero and } \\
\text { zero otherwise, where } \mathrm{n} \text { is } 12,24 \text { and } 36 \text { months }\end{array}$ & \\
\hline Positive correlation (COR_POSn) & $\begin{array}{l}\text { Equal CORRn for values of CORRn greater than zero } \\
\text { and zero otherwise, where } \mathrm{n} \text { is } 12,24 \text { and } 36 \text { months }\end{array}$ & \\
\hline Leverage $(L E V)$ & Total debt / total assets & $\begin{array}{l}\text { Breuer et al. (2019); } \\
\text { Hardin \& Hill (2008) }\end{array}$ \\
\hline Cash flow (CASHFLOW) & Funds from operations / total assets & $\begin{array}{l}\text { Chou et al. (2013); } \\
\text { Sun et al. (2015) }\end{array}$ \\
\hline Growth opportunities (GROWTH) & $\begin{array}{l}\text { Ratio of the market value of equity to the book value } \\
\text { of equity }\end{array}$ & Lundstrum (2002) \\
\hline Tangibility $(T A N)$ & $\begin{array}{l}\text { Ratio of net property, plant and equipment to total } \\
\text { assets }\end{array}$ & $\begin{array}{l}\text { Breuer et al. (2019); } \\
\text { Morri \& Beretta (2008) }\end{array}$ \\
\hline Firm size $(S I Z E)$ & Natural logarithm of total assets (in million USD) & $\begin{array}{l}\text { Morri \& Beretta (2008); } \\
\text { Sun et al. (2015) }\end{array}$ \\
\hline Equity issue (EQUITY_ISSUE) & $\begin{array}{l}\text { Dummy for the presence of stock issues }=1 \text { if } \\
\text { net issuance (retirement) of stock / total assets } \\
>0.05\end{array}$ & $\begin{array}{l}\text { Alcock \& Steiner (2017); } \\
\text { Riddiough \& Wu (2009) }\end{array}$ \\
\hline Debt issue $\left(D E B T_{-} I S S U E\right)$ & $\begin{array}{l}\text { Dummy for the presence of debt issues }=1 \text { if } \\
\text { net issuance (retirement) of debt / total assets } \\
>0.05\end{array}$ & $\begin{array}{l}\text { Alcock \& Steiner (2017); } \\
\text { Riddiough \& Wu (2009) }\end{array}$ \\
\hline Term structure $(T 10 T 3 M)$ & $\begin{array}{l}\text { Difference between yields of } 10 \text {-year treasury note } \\
\text { and 3-month treasury bill }\end{array}$ & $\begin{array}{l}\text { Frank \& Goyal (2009); } \\
\text { Ooi et al. (2010) }\end{array}$ \\
\hline Lending rate ( $\left.L E N D I N G_{-} R A T E\right)$ & Prime lending rate charged by banks & $\begin{array}{l}\text { Pavlov \& Wachter (2009); } \\
\text { Pavlov et al. (2015) }\end{array}$ \\
\hline
\end{tabular}

This table shows the definition of variables. All data are obtained from Thomson Reuters Datastream/Eikon, except for T10T3M that is obtained from the Federal Reserve Bank of St Louis's Economic Database. 
Table 2: Descriptive statistics

\begin{tabular}{|c|c|c|c|c|c|c|}
\hline & $N$ & Mean & Std. Dev. & Min. & Median & Max. \\
\hline INVEST & 1,685 & 0.160 & 0.266 & -0.321 & 0.094 & 2.841 \\
\hline$C O R \_N E G 12$ & 1,685 & -0.116 & 0.174 & -0.720 & 0.000 & 0.000 \\
\hline COR_POS12 & 1,685 & 0.145 & 0.185 & 0.000 & 0.033 & 0.672 \\
\hline COR_NEG24 & 1,521 & -0.055 & 0.105 & -0.542 & 0.000 & 0.000 \\
\hline COR_POS 24 & 1,521 & 0.129 & 0.139 & 0.000 & 0.088 & 0.555 \\
\hline COR_NEG36 & 1,365 & -0.035 & 0.075 & -0.489 & 0.000 & 0.000 \\
\hline COR_POS36 & 1,365 & 0.129 & 0.132 & 0.000 & 0.097 & 0.555 \\
\hline$L E V$ & 1,685 & 0.507 & 0.148 & 0.000 & 0.507 & 0.903 \\
\hline CASHFLOW & 1,685 & 0.051 & 0.023 & -0.012 & 0.048 & 0.141 \\
\hline GROWTH & 1,685 & 1.789 & 1.631 & -3.482 & 1.458 & 12.473 \\
\hline$T A N$ & 1,685 & 0.844 & 0.124 & 0.195 & 0.883 & 0.980 \\
\hline$S I Z E$ & 1,685 & 7.640 & 1.091 & 3.389 & 7.668 & 10.118 \\
\hline EQUITY_ISSUE & 1,685 & 0.345 & 0.475 & 0.000 & 0.000 & 1.000 \\
\hline DEBT_ISSUE & 1,685 & 0.378 & 0.485 & 0.000 & 0.000 & 1.000 \\
\hline$T 10 Y 3 M$ & 1,685 & 0.021 & 0.010 & -0.001 & 0.023 & 0.031 \\
\hline$L E N D I N G \_R A T E$ & 1,685 & 0.047 & 0.020 & 0.032 & 0.036 & 0.095 \\
\hline
\end{tabular}


Table 3: Correlation coefficients for independent variables

\begin{tabular}{|c|c|c|c|c|c|c|c|c|c|c|c|c|c|c|c|}
\hline & $(1)$ & (2) & (3) & (4) & $(5)$ & (6) & (7) & $(8)$ & (9) & $(10)$ & $(11)$ & $(12)$ & $(13)$ & $(14)$ & (15) \\
\hline (1) COR_NEG12 & 1.00 & & & & & & & & & & & & & & \\
\hline (2) COR_POS12 & $0.52^{*}$ & 1.00 & & & & & & & & & & & & & \\
\hline (3) COR_NEG24 & $0.50^{*}$ & $0.35^{*}$ & 1.00 & & & & & & & & & & & & \\
\hline (4) COR_POS24 & $0.41^{*}$ & $0.51^{*}$ & $0.49^{*}$ & 1.00 & & & & & & & & & & & \\
\hline (5) COR_NEG36 & $0.26^{*}$ & $0.26^{*}$ & $0.58^{*}$ & $0.40^{*}$ & 1.00 & & & & & & & & & & \\
\hline (6) COR_POS36 & $0.30^{*}$ & $0.43 *$ & $0.40^{*}$ & $0.71^{*}$ & $0.46^{*}$ & 1.00 & & & & & & & & & \\
\hline (7) $L E V$ & -0.02 & -0.04 & -0.03 & -0.04 & -0.00 & -0.01 & 1.00 & & & & & & & & \\
\hline (8) $C A S H F L O W$ & -0.01 & -0.03 & 0.01 & -0.04 & 0.02 & $-0.08^{*}$ & $-0.40 *$ & 1.00 & & & & & & & \\
\hline (9) GROWTH & $-0.05^{*}$ & $-0.05^{*}$ & -0.01 & $-0.08 *$ & -0.04 & $-0.11 *$ & $0.27 *$ & $0.21 *$ & 1.00 & & & & & & \\
\hline (10) $T A N$ & $-0.05^{*}$ & -0.04 & $-0.09 *$ & $-0.08^{*}$ & $-0.07 *$ & $-0.07 *$ & $0.11^{*}$ & $-0.14^{*}$ & $-0.09 *$ & 1.00 & & & & & \\
\hline (11) SIZE & 0.01 & 0.01 & 0.04 & 0.03 & $0.06^{*}$ & 0.04 & $0.07^{*}$ & $-0.13^{*}$ & $0.05^{*}$ & 0.01 & 1.00 & & & & \\
\hline (12) EQUITY_ISSUE & 0.03 & 0.05 & $0.07 *$ & 0.05 & $0.06^{*}$ & 0.03 & $-0.16^{*}$ & $-0.09 *$ & $-0.08 *$ & 0.01 & $-0.05 *$ & 1.00 & & & \\
\hline (13) DEBT_ISSUE & $-0.06^{*}$ & $-0.07 *$ & -0.03 & $-0.06^{*}$ & 0.00 & $-0.06^{*}$ & $0.07 *$ & -0.03 & 0.01 & -0.01 & $-0.10^{*}$ & $0.06^{*}$ & 1.00 & & \\
\hline (14) $T 10 Y 3 M$ & -0.02 & $0.08 *$ & $-0.16^{*}$ & -0.00 & 0.03 & $0.12 *$ & 0.01 & -0.04 & $-0.11^{*}$ & -0.00 & $0.08 *$ & 0.02 & $-0.19 *$ & 1.00 & \\
\hline (15) LENDING_RATE & $-0.12 *$ & $-0.15^{*}$ & -0.03 & $-0.16^{*}$ & -0.03 & $-0.22 *$ & 0.03 & $0.10^{*}$ & 0.01 & 0.04 & $-0.20 *$ & $-0.16^{*}$ & $0.13 *$ & $-0.39 *$ & 1.00 \\
\hline
\end{tabular}


Table 4: Underpricing of the default risk and investment

\begin{tabular}{|c|c|c|c|}
\hline & $\begin{array}{c}\text { Model 1 } \\
\left(C O R \_N E G 12\right)\end{array}$ & $\begin{array}{c}\text { Model } 2 \\
\left(C O R \_N E G 24\right)\end{array}$ & $\begin{array}{c}\text { Model 3 } \\
\left(C O R \_N E G 36\right)\end{array}$ \\
\hline COR_NEG12 & $\begin{array}{c}-0.125^{* * *} \\
(-2.813)\end{array}$ & & \\
\hline COR_POS12 & $\begin{array}{l}0.062 * \\
(1.821)\end{array}$ & & \\
\hline COR_NEG24 & & $\begin{array}{c}0.025 \\
(0.514)\end{array}$ & \\
\hline COR_POS24 & & $\begin{array}{c}0.051 \\
(0.750)\end{array}$ & \\
\hline COR_NEG36 & & & $\begin{array}{c}0.037 \\
(0.376)\end{array}$ \\
\hline COR_POS36 & & & $\begin{array}{c}0.036 \\
(0.608)\end{array}$ \\
\hline$L E V$ & $\begin{array}{l}-0.272 * * \\
(-2.149)\end{array}$ & $\begin{array}{c}-0.153 \\
(-1.242)\end{array}$ & $\begin{array}{c}-0.085 \\
(-0.609)\end{array}$ \\
\hline CASHFLOW & $\begin{array}{l}0.932 * \\
(1.922)\end{array}$ & $\begin{array}{l}1.087 * * \\
(2.150)\end{array}$ & $\begin{array}{l}1.212 * * \\
(2.168)\end{array}$ \\
\hline GROWTH & $\begin{array}{c}0.023 * * * \\
(3.336)\end{array}$ & $\begin{array}{c}0.026 * * * \\
(2.647)\end{array}$ & $\begin{array}{l}0.025 * * \\
(2.488)\end{array}$ \\
\hline$T A N$ & $\begin{array}{c}-0.114 \\
(-0.713)\end{array}$ & $\begin{array}{c}-0.086 \\
(-0.529)\end{array}$ & $\begin{array}{c}-0.153 \\
(-0.831)\end{array}$ \\
\hline SIZE & $\begin{array}{c}-0.136^{* * *} \\
(-5.117)\end{array}$ & $\begin{array}{c}-0.113 * * * \\
(-4.749)\end{array}$ & $\begin{array}{c}-0.116^{* * *} \\
(-4.353)\end{array}$ \\
\hline EQUITY_ISSUE & $\begin{array}{c}0.063 * * * \\
(3.916)\end{array}$ & $\begin{array}{c}0.061 * * * \\
(3.818)\end{array}$ & $\begin{array}{c}0.051 * * * \\
(3.154)\end{array}$ \\
\hline DEBT_ISSUE & $\begin{array}{c}0.050 * * * \\
(3.448)\end{array}$ & $\begin{array}{c}0.045^{* * *} \\
(3.264)\end{array}$ & $\begin{array}{c}0.043 * * * \\
(2.978)\end{array}$ \\
\hline$T 10 Y 3 M$ & $\begin{array}{c}-5.431 * * * \\
(-7.431)\end{array}$ & $\begin{array}{c}-3.686^{* * *} \\
(-5.010)\end{array}$ & $\begin{array}{c}-3.555 * * * \\
(-4.191)\end{array}$ \\
\hline$L E N D I N G \_R A T E$ & $\begin{array}{c}-2.450 * * * \\
(-6.152)\end{array}$ & $\begin{array}{l}-1.438 * * \\
(-2.475)\end{array}$ & $\begin{array}{l}-1.324 * * \\
(-2.121)\end{array}$ \\
\hline CONSTANT & $\begin{array}{c}1.507 * * * \\
(5.234)\end{array}$ & $\begin{array}{c}1.169^{* * * *} \\
(4.338)\end{array}$ & $\begin{array}{c}1.210 * * * \\
(3.875)\end{array}$ \\
\hline No. of Obs. & 1,685 & 1,521 & 1,365 \\
\hline$R^{2}$ & 0.126 & 0.100 & 0.098 \\
\hline \multicolumn{4}{|c|}{$\begin{array}{l}\text { The table reports regression results, which include coefficients and } t \text {-statistics } \\
\text { in brackets, for factors affecting REITs' investment. Model } 1 \text { uses } \\
C O R \_N E G 12 \text { to capture the underpricing of the default risk. Models } 2 \text { and } 3 \\
\text { use } C O R \_N E G 24 \text { and } C O R \_N E G 36 \text { to capture the underpricing of the default } \\
\text { risk, respectively. Hausman's specification test indicates that the fixed effects } \\
\text { model is preferable for the data (see Panel A of Table A. } 1 \text { in the Appendix). } \\
\text { Standard errors are clustered by the firm level to be robust to autocorrelation } \\
\text { and heteroscedasticity. The definition of variables is presented in Table } 1 \text {. } \\
* \mathrm{p}<0.10, * * \mathrm{p}<0.05, * * * \mathrm{p}<0.01\end{array}$} \\
\hline
\end{tabular}


Table 5: Controlling for crisis periods

\begin{tabular}{|c|c|c|c|}
\hline & $\begin{array}{c}\text { Model 1 } \\
\left(C O R \_N E G 12\right)\end{array}$ & $\begin{array}{c}\text { Model } 2 \\
\left(C O R \_N E G 24\right)\end{array}$ & $\begin{array}{c}\text { Model 3 } \\
\left(C O R \_N E G 36\right)\end{array}$ \\
\hline D_CRISIS & $\begin{array}{l}-0.030 * \\
(-1.657)\end{array}$ & $\begin{array}{c}-0.051 * * * \\
(-3.052)\end{array}$ & $\begin{array}{c}-0.056^{* * *} \\
(-3.222)\end{array}$ \\
\hline COR_NEG12 & $\begin{array}{l}-0.117 * * \\
(-2.597)\end{array}$ & & \\
\hline COR_NEG12 $\times$ D_CRISIS & $\begin{array}{c}0.152 \\
(0.917)\end{array}$ & & \\
\hline COR_POS12 & $\begin{array}{l}0.074 * * \\
(2.047)\end{array}$ & & \\
\hline COR_NEG24 & & $\begin{array}{c}0.022 \\
(0.438)\end{array}$ & \\
\hline COR_NEG $24 \times$ D_CRISIS & & $\begin{array}{c}0.089 \\
(0.408)\end{array}$ & \\
\hline COR_POS24 & & $\begin{array}{c}0.088 \\
(1.256)\end{array}$ & \\
\hline COR_NEG36 & & & $\begin{array}{c}0.012 \\
(0.114)\end{array}$ \\
\hline COR_NEG36 $\times$ D_CRISIS & & & $\begin{array}{c}0.090 \\
(0.341)\end{array}$ \\
\hline COR_POS36 & & & $\begin{array}{c}0.079 \\
(1.365)\end{array}$ \\
\hline Firm-specific variables & Yes & Yes & Yes \\
\hline Market variables & Yes & Yes & Yes \\
\hline No. of Obs. & 1,685 & 1,521 & 1,365 \\
\hline$R^{2}$ & 0.128 & 0.104 & 0.103 \\
\hline \multicolumn{4}{|c|}{ 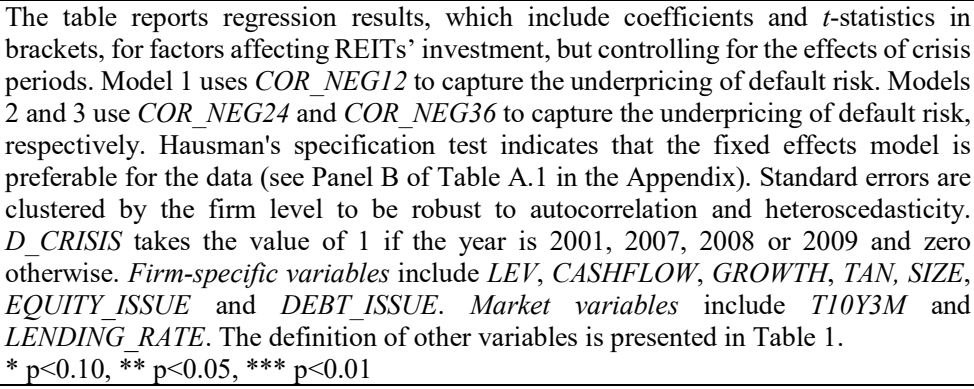 } \\
\hline
\end{tabular}


Table 6: Controlling instrumental variables

\begin{tabular}{|c|c|c|c|c|c|c|}
\hline & \multicolumn{2}{|c|}{ Panel A } & \multicolumn{2}{|c|}{ Panel B } & \multicolumn{2}{|c|}{ Panel C } \\
\hline & $\begin{array}{l}\text { First } \\
\text { stage }\end{array}$ & $\begin{array}{c}\text { Second } \\
\text { stage }\end{array}$ & $\begin{array}{l}\text { First } \\
\text { stage }\end{array}$ & $\begin{array}{c}\text { Second } \\
\text { stage }\end{array}$ & $\begin{array}{l}\text { First } \\
\text { stage }\end{array}$ & $\begin{array}{c}\text { Second } \\
\text { stage }\end{array}$ \\
\hline & Model 1 & Model 2 & Model 3 & Model 4 & Model 5 & Model 6 \\
\hline COR_NEG12 & & $\begin{array}{l}-0.342 * * \\
(-2.280)\end{array}$ & & & & \\
\hline COR_POS12 & $\begin{array}{c}0.343 * * * \\
(21.145)\end{array}$ & $\begin{array}{c}0.163 * * \\
(2.193)\end{array}$ & & & & \\
\hline COR_NEG24 & & & & $\begin{array}{c}-0.771 * * * \\
(-2.890)\end{array}$ & & \\
\hline COR_POS24 & & & $\begin{array}{c}0.331 * * * \\
(17.249)\end{array}$ & $\begin{array}{c}0.336^{* * *} \\
(3.683)\end{array}$ & & \\
\hline COR_NEG36 & & & & & & $\begin{array}{c}-1.267 \\
(-1.574)\end{array}$ \\
\hline$C O R \_P O S 36$ & & & & & $\begin{array}{c}0.174 * * * \\
(10.933)\end{array}$ & $\begin{array}{l}0.320 * \\
(1.826)\end{array}$ \\
\hline BONUS_GR & $\begin{array}{c}-5.368^{* * *} \\
(-9.900)\end{array}$ & & $\begin{array}{c}-2.936^{* * *} \\
(-9.046)\end{array}$ & & $\begin{array}{c}-0.257 \\
(-1.042)\end{array}$ & \\
\hline$W A G E_{-} G R$ & $\begin{array}{c}4.306^{* * *} \\
(8.603)\end{array}$ & & $\begin{array}{c}2.648 * * * \\
(8.452)\end{array}$ & & $\begin{array}{c}0.016 \\
(0.068)\end{array}$ & \\
\hline Firm-specific variables & Yes & Yes & Yes & Yes & Yes & Yes \\
\hline Market variables & Yes & Yes & Yes & Yes & Yes & Yes \\
\hline No. of Obs. & 1,558 & 1,558 & 1,504 & 1,504 & 1,348 & 1,348 \\
\hline SW multivariate $F$ test & 85.11 & & 46.10 & & 23.54 & \\
\hline$p$-value & 0.00 & & 0.00 & & 0.00 & \\
\hline Hansen $J$ statistic & 0.91 & & 1.04 & & 3.77 & \\
\hline$p$-value & 0.34 & & 0.31 & & 0.06 & \\
\hline \multicolumn{7}{|c|}{ 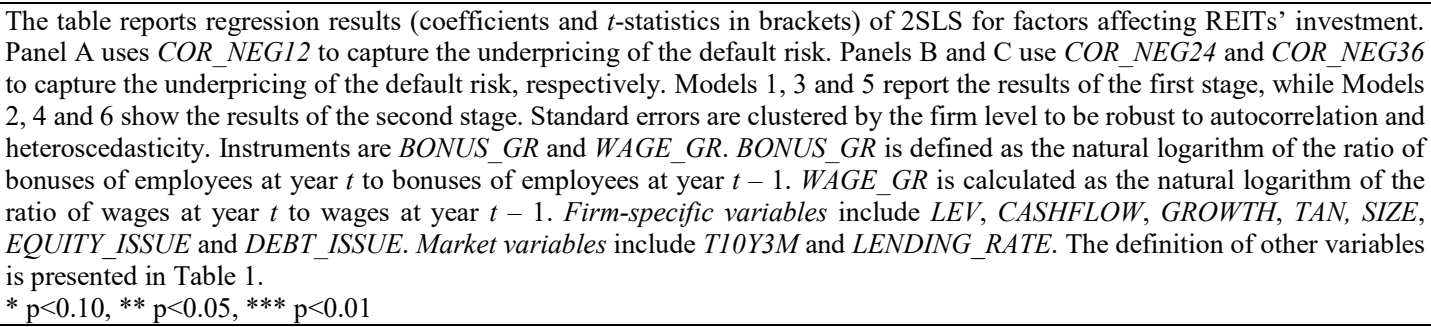 } \\
\hline
\end{tabular}


Table 7: Alternative measures of investment

\begin{tabular}{|c|c|c|c|c|c|c|}
\hline & \multicolumn{3}{|c|}{ Panel A: INVEST-CASH } & \multicolumn{3}{|c|}{ Panel B: INVEST-DEPR } \\
\hline & Model 1 & Model 2 & Model 3 & Model 4 & Model 5 & Model 6 \\
\hline \multirow[t]{2}{*}{ COR_NEG12 } & $-0.059 * *$ & & & $-0.057 * * *$ & & \\
\hline & $(-2.126)$ & & & $(-2.618)$ & & \\
\hline \multirow[t]{2}{*}{ COR_POS12 } & 0.017 & & & 0.016 & & \\
\hline & $(0.869)$ & & & $(0.945)$ & & \\
\hline \multirow[t]{2}{*}{ COR_NEG24 } & & 0.037 & & & 0.029 & \\
\hline & & $(1.333)$ & & & $(1.206)$ & \\
\hline \multirow[t]{2}{*}{ COR_POS24 } & & -0.038 & & & -0.025 & \\
\hline & & $(-1.309)$ & & & $(-1.014)$ & \\
\hline \multirow[t]{2}{*}{ COR_NEG36 } & & & 0.051 & & & 0.037 \\
\hline & & & $(1.035)$ & & & $(0.791)$ \\
\hline \multirow[t]{2}{*}{ COR_POS36 } & & & -0.042 & & & -0.028 \\
\hline & & & $(-1.379)$ & & & $(-1.042)$ \\
\hline Firm-specific variables & Yes & Yes & Yes & Yes & Yes & Yes \\
\hline Market variables & Yes & Yes & Yes & Yes & Yes & Yes \\
\hline No. of Obs. & 1,701 & 1,537 & 1,381 & 1,654 & 1,493 & 1,340 \\
\hline$R^{2}$ & 0.092 & 0.075 & 0.073 & 0.134 & 0.107 & 0.101 \\
\hline \multicolumn{7}{|c|}{ 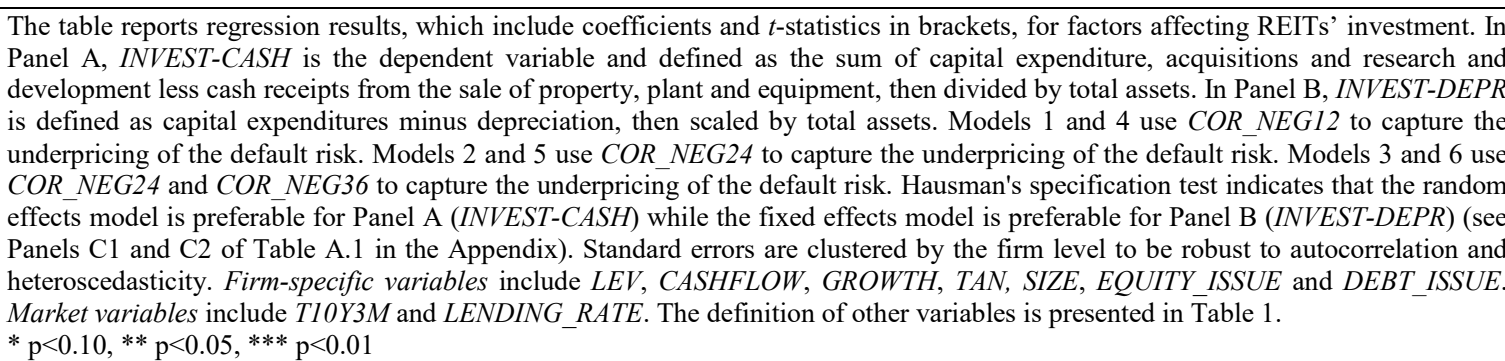 } \\
\hline
\end{tabular}


Table 8: Alternative measures of underpriced default risk

\begin{tabular}{|c|c|c|c|c|c|c|}
\hline & \multicolumn{2}{|c|}{ Panel A: INVEST } & \multicolumn{2}{|c|}{ Panel B: INVEST-CASH } & \multicolumn{2}{|c|}{ Panel C: INVEST-DEPR } \\
\hline & Model 1 & Model 2 & Model 3 & Model 4 & Model 5 & Model 6 \\
\hline \multirow[t]{2}{*}{$N E W_{-} C O R \_N E G$} & $0.124 * * *$ & & $0.051 * * *$ & & $0.051 * * *$ & \\
\hline & $(5.257)$ & & $(3.147)$ & & $(4.224)$ & \\
\hline \multirow[t]{2}{*}{$D L I$} & & $-0.152 * *$ & & -0.034 & & $-0.072 * *$ \\
\hline & & $(-2.025)$ & & $(-0.795)$ & & $(-2.231)$ \\
\hline Firm-specific variables & Yes & Yes & Yes & Yes & Yes & Yes \\
\hline Market variables & Yes & Yes & Yes & Yes & Yes & Yes \\
\hline No. of Obs. & 1,117 & 1,428 & 1,122 & 1,435 & 1,100 & 1,399 \\
\hline$R^{2}$ & 0.142 & 0.136 & 0.091 & 0.052 & 0.135 & 0.087 \\
\hline
\end{tabular}

The table reports regression results, which include coefficients and $t$-statistics in brackets, for factors affecting REITs' investment. Dependent variables are INVEST, INVEST-CASH and INVEST-DEPR in Panels A, B and C, respectively. Models 1, 3 and 5 use $N E W$ COR NEG to capture the underpricing of the default risk. Models 2, 4 and 6 use $D L I$ to test the influence of the default probability on investment. Standard errors are clustered by the firm level to be robust to autocorrelation and heteroscedasticity. $N E W$ COR NEG is an indicator variable that takes the value of 1 if a firm-year observation has simultaneously a positive change in $D L I$ and a positive change in the ratio of total lines of credit available to total assets and zero otherwise. $D L I$ is calculated from Eq. (3). Firm-specific variables include LEV, CASHFLOW, GROWTH, TAN, SIZE, EQUITY_ISSUE and DEBT_ISSUE. Market variables include T10Y3M and LENDING RATE. The definition of other variables is presented in Table 1.

$* \mathrm{p}<0.10, * * \mathrm{p}<0.05, * * * \mathrm{p}<0.01$ 
Table 9: Underpricing of the default risk and investment in a joint sample

\begin{tabular}{|c|c|c|c|c|c|c|}
\hline & \multicolumn{3}{|c|}{ Panel A: REIT vs. REOC } & \multicolumn{3}{|c|}{ Panel B: REIT vs. non-RE } \\
\hline & Model 1 & Model 2 & Model 3 & Model 4 & Model 5 & Model 6 \\
\hline \multirow[t]{2}{*}{ COR_NEG12 } & $-0.118 * *$ & & & 0.013 & & \\
\hline & $(-2.475)$ & & & $(0.458)$ & & \\
\hline \multirow[t]{2}{*}{ D_REIT $\times$ COR_NEG12 } & -0.309 & & & $-0.124 * * *$ & & \\
\hline & $(-1.091)$ & & & $(-2.850)$ & & \\
\hline \multirow[t]{2}{*}{ COR_POS12 } & $0.089^{* *}$ & & & $0.050 * *$ & & \\
\hline & $(2.251)$ & & & $(2.018)$ & & \\
\hline \multirow[t]{2}{*}{$C O R \_N E G 24$} & & 0.002 & & & 0.058 & \\
\hline & & $(0.034)$ & & & $(1.409)$ & \\
\hline \multirow[t]{2}{*}{ D_REIT $\times$ COR_NEG 24} & & -0.258 & & & -0.064 & \\
\hline & & $(-0.866)$ & & & $(-1.261)$ & \\
\hline \multirow[t]{2}{*}{ COR_POS24 } & & 0.065 & & & 0.015 & \\
\hline & & $(0.902)$ & & & $(0.426)$ & \\
\hline \multirow[t]{2}{*}{$C O R \_N E G 36$} & & & 0.028 & & & $0.233^{*}$ \\
\hline & & & $(0.286)$ & & & $(4.824)$ \\
\hline \multirow[t]{2}{*}{ D_REIT $\times$ COR_NEG36 } & & & -0.471 & & & -0.054 \\
\hline & & & $(-0.784)$ & & & $(-0.601)$ \\
\hline \multirow[t]{2}{*}{ COR_POS36 } & & & 0.044 & & & -0.054 \\
\hline & & & $(0.736)$ & & & $(-1.574)$ \\
\hline Firm-specific variables & Yes & Yes & Yes & Yes & Yes & Yes \\
\hline Market variables & Yes & Yes & Yes & Yes & Yes & Yes \\
\hline \multirow[t]{2}{*}{ CONSTANT } & $1.989 * * *$ & $1.992 * * *$ & $1.822 * * *$ & $2.222 * * *$ & $2.286^{* * *}$ & $2.399 * * *$ \\
\hline & $(6.438)$ & $(5.426)$ & $(5.251)$ & $(19.140)$ & $(18.320)$ & $(17.765)$ \\
\hline No. of Obs. & 2,246 & 2,034 & 1,829 & 32,637 & 29,892 & 27,228 \\
\hline$R^{2}$ & 0.171 & 0.151 & 0.144 & 0.073 & 0.072 & 0.078 \\
\hline \multicolumn{7}{|c|}{ 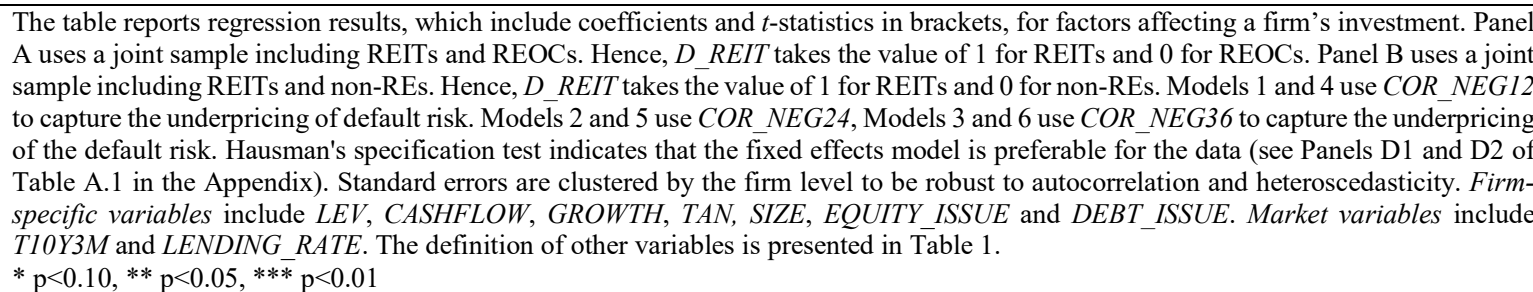 } \\
\hline
\end{tabular}




\section{Appendix}

Table A.1: Fixed effects models vs random effects model: Sargan-Hansen test results

\begin{tabular}{|c|c|c|c|}
\hline & $\begin{array}{c}\text { Model } 1 \\
\left(C O R_{-} N E G 12\right)\end{array}$ & $\begin{array}{c}\text { Model } 2 \\
\left(C O R \_N E G 24\right)\end{array}$ & $\begin{array}{c}\text { Model } 3 \\
\left(C O R \_N E G 36\right)\end{array}$ \\
\hline \multicolumn{4}{|c|}{ Panel A: Underpricing of the default risk and investment } \\
\hline Sargan-Hansen statistic & 74.495 & 58.803 & 57.904 \\
\hline$p$-value & $<.001^{\mathrm{fe}}$ & $<.001^{\mathrm{fe}}$ & $<.001^{\mathrm{fe}}$ \\
\hline \multicolumn{4}{|c|}{ Panel B: Controlling for effects of the crisis period } \\
\hline Sargan-Hansen statistic & 92.610 & 79.233 & 52.886 \\
\hline$p$-value & $<.001^{\mathrm{fe}}$ & $<.001^{\mathrm{fe}}$ & $<.001^{\mathrm{fe}}$ \\
\hline \multicolumn{4}{|c|}{ Panel C1: Alternative measure of investment (INVEST-CASH) } \\
\hline Sargan-Hansen statistic & 39.252 & 37.807 & 50.117 \\
\hline$p$-value & $<.001^{\mathrm{fe}}$ & $<.001^{\mathrm{fe}}$ & $<.001^{\mathrm{fe}}$ \\
\hline \multicolumn{4}{|c|}{ Panel C2: Alternative measure of investment (INVEST-DEPR) } \\
\hline Sargan-Hansen statistic & 45.603 & 37.387 & 59.919 \\
\hline$p$-value & $<.001^{\mathrm{fe}}$ & $<.001^{\mathrm{fe}}$ & $<.001^{\text {fe }}$ \\
\hline \multicolumn{4}{|c|}{ Panel D1: REITs vs. non-REs } \\
\hline Sargan-Hansen statistic & 471.676 & 339.204 & 312.618 \\
\hline$p$-value & $<.001^{\mathrm{fe}}$ & $<.001^{\mathrm{fe}}$ & $<.001^{\text {fe }}$ \\
\hline \multicolumn{4}{|c|}{ Panel D2: REITs vs. REOCs } \\
\hline Sargan-Hansen statistic & 35.601 & 87.320 & 78.760 \\
\hline$p$-value & $<.001^{\mathrm{fe}}$ & $<.001^{\mathrm{fe}}$ & $<.001^{\mathrm{fe}}$ \\
\hline \multicolumn{4}{|c|}{$\begin{array}{l}\text { The table reports the results of the Sargan-Hansen test for the COR_NEG12 model, COR_NEG24 model and } \\
C O R \_N E G 36 \text { model. The } p \text {-value is the probability, under the null hypothesis }\left(\mathrm{H}_{0}\right) \text { : difference in coefficients is } \\
\text { not systematic, of obtaining a result equal to or more extreme than what was actually observed. } \\
\text { fe. the test indicates that the fixed-effects model is preferable. }\end{array}$} \\
\hline
\end{tabular}


Table A.2: Descriptive statistics of the non-RE and REOC samples

\begin{tabular}{|c|c|c|c|c|c|c|}
\hline & $N$ & Mean & Std. Dev. & Min. & Median & Max. \\
\hline \multicolumn{7}{|c|}{ Panel A: Non-REs } \\
\hline INVEST & 30,952 & 0.210 & 0.717 & -3.030 & 0.114 & 7.095 \\
\hline COR_NEG12 & 30,952 & -0.109 & 0.165 & -0.663 & 0.000 & 0.000 \\
\hline COR_POS12 & 30,952 & 0.137 & 0.180 & 0.000 & 0.032 & 0.704 \\
\hline COR_NEG24 & 28,361 & -0.072 & 0.117 & -0.524 & 0.000 & 0.000 \\
\hline COR_POS 24 & 28,361 & 0.114 & 0.143 & 0.000 & 0.047 & 0.603 \\
\hline COR_NEG36 & 25,855 & -0.055 & 0.098 & -0.482 & 0.000 & 0.000 \\
\hline COR_POS36 & 25,855 & 0.113 & 0.135 & 0.000 & 0.060 & 0.576 \\
\hline$L E V$ & 30,952 & 0.204 & 0.196 & 0.000 & 0.170 & 0.848 \\
\hline CASHFLOW & 30,952 & 0.051 & 0.231 & -1.966 & 0.092 & 0.415 \\
\hline GROWTH & 30,952 & 3.290 & 6.525 & -21.412 & 2.084 & 52.086 \\
\hline$T A N$ & 30,952 & 0.266 & 0.240 & 0.002 & 0.184 & 0.920 \\
\hline$S I Z E$ & 30,952 & 6.305 & 2.182 & -0.320 & 6.362 & 11.111 \\
\hline EQUITY_ISSUE & 30,952 & 0.312 & 0.463 & 0.000 & 0.000 & 1.000 \\
\hline DEBT_ISSUE & 30,952 & 0.204 & 0.403 & 0.000 & 0.000 & 1.000 \\
\hline$T 10 Y 3 M$ & 30,952 & 0.021 & 0.009 & -0.001 & 0.023 & 0.031 \\
\hline LENDING_RATE & 30,952 & 0.044 & 0.016 & 0.032 & 0.034 & 0.083 \\
\hline \multicolumn{7}{|c|}{ Panel B: REOCs } \\
\hline INVEST & 561 & 0.196 & 0.758 & -2.130 & 0.065 & 6.913 \\
\hline$C O R \_N E G 12$ & 561 & -0.101 & 0.156 & -0.632 & 0.000 & 0.000 \\
\hline COR_POS12 & 561 & 0.136 & 0.174 & 0.000 & 0.028 & 0.639 \\
\hline COR_NEG24 & 510 & -0.064 & 0.105 & -0.532 & 0.000 & 0.000 \\
\hline COR_POS24 & 510 & 0.104 & 0.125 & 0.000 & 0.053 & 0.517 \\
\hline COR_NEG36 & 460 & -0.053 & 0.089 & -0.392 & 0.000 & 0.000 \\
\hline COR_POS36 & 460 & 0.094 & 0.112 & 0.000 & 0.053 & 0.485 \\
\hline$L E V$ & 561 & 0.364 & 0.284 & 0.000 & 0.312 & 0.965 \\
\hline CASHFLOW & 561 & 0.025 & 0.124 & -0.898 & 0.021 & 0.666 \\
\hline GROWTH & 561 & 2.990 & 7.878 & -39.286 & 1.195 & 46.783 \\
\hline$T A N$ & 561 & 0.493 & 0.318 & 0.003 & 0.568 & 0.986 \\
\hline$S I Z E$ & 561 & 4.958 & 1.819 & 0.149 & 4.976 & 9.011 \\
\hline EQUITY_ISSUE & 561 & 0.349 & 0.477 & 0.000 & 0.000 & 1.000 \\
\hline DEBT_ISSUE & 561 & 0.321 & 0.467 & 0.000 & 0.000 & 1.000 \\
\hline$T 10 Y 3 M$ & 561 & 0.021 & 0.010 & -0.001 & 0.023 & 0.031 \\
\hline LENDING_RATE & 561 & 0.046 & 0.019 & 0.032 & 0.036 & 0.095 \\
\hline
\end{tabular}

The table shows the descriptive statistics (number of observations, mean, standard deviation, minimum, median and maximum) of the non-REs and REOC samples from 1999 to 2015. The definition of variables is presented in Table 1. 
Table A.3: Analysis of the matched sample

\begin{tabular}{lccc}
\hline & REIT & Non-RE & Matched sample \\
\hline COR_NEG12 & $-0.223^{* *}$ & 0.033 & 0.040 \\
& $(-2.296)$ & $(0.302)$ & $(0.396)$ \\
COR_POS12 & 0.091 & $0.155^{*}$ & $0.114^{*}$ \\
& $(1.418)$ & $(1.706)$ & $(1.939)$ \\
D_REIT $\times$ COR_NEG12 & & & $-0.254^{*}$ \\
& & & $(-1.917)$ \\
Firm-specific variables & Yes & Yes & Yes \\
Market variables & Yes & Yes & Yes \\
CONSTANT & $1.829^{* * *}$ & $2.401^{* * *}$ & $2.287^{* * *}$ \\
& $(4.355)$ & $(3.908)$ & $(5.710)$ \\
No. of Obs. & 797 & 1,530 & 2,327 \\
$\boldsymbol{R}^{2}$ & 0.162 & 0.204 & 0.184 \\
\hline
\end{tabular}

The table reports regression results, which include coefficients and $t$-statistics in brackets, for factors affecting a firm's investment. Column "REIT" reports the results of the REIT sample. Columns 2 and 3 report the results of the non-RE and matched samples, respectively. Standard errors are clustered by the firm level to be robust to autocorrelation and heteroscedasticity. $D R E I T$ takes the value of 1 for REITs and 0 for non-REs. Firm-specific variables include LEV, CASHFLOW, GROWTH, TAN, SIZE, EQUITY_ISSUE and DEBT_ISSUE. Market variables include T1OY3M and LENDING RATE. The definition of other variables is presented in Table 1.

$* \mathrm{p}<0.10, * * \mathrm{p}<0.05, * * * \mathrm{p}<0.01$ 